\title{
VBP. Valparaíso, Mümbai, Persépolis
}

\author{
IVÁN ALBERTO MÉNDEZ OLIVARES \\ Departamento de Diseño. Facultad de Arquitectura. Universidad de Chile \\ iamendez34@gmail.com
}

\begin{abstract}
Resumen
A partir de un caso de abigeato -robo de ganado- se estructura la puesta en cuadro de Valparaíso, mi amor (1968), película que visiona e indaga respecto de la situación de pobreza y abandono de niños y niñas de la ciudad-puerto como paradigma de las inequidades sociales, políticas y culturales del Chile de los '60. Por su parte, la amarga poética de Saalam Bombay (1988) -la otra ciudad puerto, en este caso de la India- también explora las características e impacto social y cultural de la infancia abandonada como cruda y dramática realidad social. Finalmente, en la película animada Persépolis (2000), se exploran la infancia, la cartografía cultural del sujeto y libertades ciudadanas en anacrónica disyunción al poder del Estado Teocrático. La curatoría de este tríptico cinematográfico examina, sitúa y desvela los pliegues y repliegues de la memoria y territorio de ciudades patrimonio cultural y arqueológico de la humanidad, cuyas geografías se orillan a través de mojones de pobreza y marginalidad infantil, las cuales se representan licuadas a fundamentalismos de mercado y religiosos.
\end{abstract}

Palabras clave: Cine, infancia, pobreza, patrimonio, mercado, fundamentalismo.

\begin{abstract}
From a case of theft of cattle, the putting is structured in picture of Valparaiso, my love (1968), movie that views and investigates respect of the situation of poverty and abandon of children of the city port such as paradigm of the social, political and cultural inequities from Chile of 60's. For its part, the bitter poetics of Saalam Bombay (1988) -another city port, in this case of the India- also it explores the characteristics and social and cultural impact of the infancy left as hard and dramatic social reality. Finally, in the animated movie Persépolis (2000), it explores the infancy, the cultural cartography of the subject and civil freedoms in anachronistic disjunction to the power of the Theocratic State. The Curatorium of this cinematographic triptych examines, places and shows the folds and doublings of the memory and territory of heritage cities cultural and archaeological of the humanity, which geographies are edged across milestones of poverty and infantile marginality, which are represented liquefied to market and religious' fundamentalism.
\end{abstract}


Key words: Cinema, infancy, poverty, heritage, market, fundamentalism.

Sumario: 1.- Valparaíso; ciudad y ambiente social de los '60. 2.- Mumbai; ciudad y mosaico social en los '80. 3.- Persépolis; la ciudad arqueológica, la ciudad sitiada. 4.Bibliografía.

Me atraen las películas que antes que definir al ser metafísico, traten de definir al ser físico, la realidad objetiva (Aldo Francia, 1968) ${ }^{1}$

\section{Valparaíso; ciudad y ambiente social de los '60}

A partir de un caso de abigeato -robo de ganado- se estructura la puesta en cuadro de Valparaíso, mi amor (1968). Esta película visiona e indaga respecto de la situación de pobreza y abandono de niños y niñas de la ciudad puerto como paradigma de las inequidades sociales, políticas y culturales del Chile de los ' $60^{2}$. La idea de Aldo Francia era plasmar en imágenes el desamparo, la falta de alegría y el ambiente melancólico de su ciudad natal. Para ello no bastaba una buena trama, había que agregar una búsqueda formal acorde con esa combinación de "amor-odio" por Valparaíso: la vida es dura en el Puerto, si se es un niño de barrio pobre con el padre en la cárcel. Pero es un tipo de vida y podría ser peor en un lugar más lúgubre ${ }^{3}$. La idea de A. Francia consiste en una comunicación directa con el público, ajena a excesos de metáforas y analogías, busca los dispositi-

\footnotetext{
${ }^{1}$ Viene al caso recordar que la película de Aldo Francia corresponde al período catalogado como nuevo cine chileno de la década del '60. La propuesta de los cineastas estaba en correspondencia con los aires de cambio y revolución político-social. Sin embargo, como se verá más adelante, esta no es la premisa de la película objetivo de nuestro interés, lo cual, intuitivamente, le asigna un rango de novedad y vigencia a la fecha.

${ }^{2}$ En la actualidad el PIB de Chile llega a U\$ 19.000 (actualizado según el ppc) Esto significa que se ha quintuplicado el producto per cápita en 40 años. A este respecto, los índices de la modernización económica de Chile ilustran cifras macroeconómicas descollantes, las cuales, sin embargo, aparecen licuadas frente a los incontestables índices de pobreza infantil, que arrojan cifras preocupantes e incómodas al modelo. Revisar www.casen 2011.cl

${ }^{3}$ La curatoría secciona a través de Persépolis los acontecimientos internos de Irán y la posterior guerra con Irak, lo cual se gráfica como mosaico lúgubre al imaginario de la infancia del Puerto de Valparaíso de los años '60.
} 
vos y circuitos de funcionamiento de una clase social marginal, su cotidianeidad, la exploración de gestos y actitudes: por ejemplo, el nacimiento de uniones espontáneas como la de Mario y María ${ }^{4} \mathrm{o}$, el hecho de la indiferencia ante la muerte o la prostitución; como el caso del taxista, quien era vecino y amigo de la familia y siguió siéndolo, pese a la violación de Antonia. Por esto, resulta explícita la secuencia del entierro del más pequeño de los niños, en la cual participa el taxista ante la resignada naturalidad del entorno familiar.

Si al subdesarrollo le asignamos un vector, debemos referirnos necesariamente a la pobreza que afecta tanto a los que están inmersos en ella, como a los espectadores; puesto que estos recuerdan a cada paso su deuda social con aquellos que no pueden constituirse en observadores del drama, porque son protagonistas y el hambre los invisibiliza, hasta licuar y esparcirlos socialmente. Las imágenes de la película operan como proceso de autoconocimiento en tanto somos capaces de rescatar la cultura popular que estas encierran. El filme trata sobre niños, sobre niños pobres, maltratados, sobre los niños que sufren. Sin embargo, en profundidad, la película aborda el conflicto de la pobreza sin agredir al espectador, por el contrario, lo invita a la reflexión, al autoconocimiento, a la información ${ }^{5}$.

Del punto de vista formal la película obtura una realidad que no aparece desvirtuada por una excesiva prolijidad técnica; así la veracidad de las imágenes de Valparaíso, mi amor, se obtienen mediante la utilización de tonos grises, los cuales funcionan como elementos denotativos de una situación en que el desamparo se vuelve protagonista. Estilo que se emparenta a categorías estéticas del cine neorrealista -ausencia de contrastes y empleo de tonos grises como un informativo de prensa de la época-, lo que produce un acercamiento a la realidad, a la textura y color local de las calles del barrio-puerto.

Aldo Francia tenía en mente la creación de una película en que el mensaje fuese claro pero no evidente, donde el aspecto formal estuviese tratado estéticamente, en pos del drama de la "infancia abandonada", puesto que para él existía la preocupación por esos niños, había un elemento humanista: este rasgo se patenta en

\footnotetext{
${ }^{4}$ Mario es el padre y María la comadre que asume la protección de los hijos, a saber: Marcelo, Chirigua, Antonia y Ricardo, los protagonistas de la película.

${ }^{5}$ Extracto de la entrevista realizada por el suscrito al director Aldo Francia. Valparaíso, 1988.
} 
la medida que persigue el rescate del hombre en cuanto tal, su condición de ser pensante, lo que implica una posición ética frente a lo que se investiga, así Valparaíso, mi amor emerge como manifiesto humanista, cuyo principal propósito es el análisis de pequeñas estructuras sociales, las que llevarán a una mejor comprensión de la estructura humana. Por ejemplo, el enfoque dado a la historia de Antonia, indicado más arriba, capta la ruptura de sus sueños infantiles en un drama anónimo, el cual se universaliza en la medida que representa la vida de miles de niños, no sólo del puerto, sino del mundo ${ }^{6}$.

En Valparaíso, mi amor, se insta al espectador a realizar un análisis distanciado, donde el factor emocional se activa solo para despertar una preocupación profunda, que partiendo del choque emotivo se prolongue hacia un estado de reflexión que no abandone al espectador al caer el telón, sino que lo persiga, obligándolo al autoanálisis y a la autocrítica (Sanjinés, 1979: 84). Formalmente, esto se consigue mediante la utilización de determinados planos y movimientos de cámara. En la película la cámara se sitúa donde estaría el espectador medianamente bien colocado, nunca en una posición preferencial, ahí donde este está medio tapado por la gente, un poco atrás; porque lo que hay que mostrar es el acontecimiento más el punto de vista ${ }^{7}$. Es un estilo de cámara móvil: seguimiento de personajes, planos

\footnotetext{
${ }^{6}$ A este respecto viene al caso señalar a Malala Yousafzai, niña que adquirió relevancia internacional hace tres años, cuando se conoció su identidad después de explicar bajo pseudónimo en un blog el régimen de terror impuesto por los talibanes en su región natal del Valle de Swat, en el extremo norte de Pakistán. Aquella osadía y la de su familia, que la animó a seguir yendo a la escuela a pesar de la prohibición de los integristas contra la educación de niñas, le valió duras amenazas del grupo talibán local. La consecuencia de esta actitud ocurrió el 9 de octubre de 2012, dos hombres detuvieron el vehículo escolar en que viajaba Malala, preguntaron su nombre y le dispararon a ella y a sus compañeras de colegio. Los talibanes reivindicaron el ataque en un extenso comunicado enviado a medios locales en el que afirmaban que Malala fue atacada por su papel pionero en la prédica del secularismo y de la llamada ilustración moderada. El texto, firmado por el portavoz de los talibanes agrupados bajo las siglas TTP, Ensanulá Ehsán, recurre a pasajes del Corán para justificar el ataque a niñas y dice que matar a Malala era una obligación bajo la 'sharía' (ley islámica). Hoy, la niña se recupera en el hospital Queen Elizabeth de Birmingham, Inglaterra. Texto completo en http://actualidad.rt.com/actualidad/view/55526pakistan-pacifista-anos-abaleada-swat. También consultar en www.abc.es/20121026/internacional/abci-padre-malala-visita-hospital-201210261756.htmn

${ }^{7}$ Entrevista realizada por el suscrito al destacado cineasta chileno R. Ruiz, en el marco de la tesis de pregrado en Historia del Arte, 1988.
} 
largos, que a veces surgían en terreno, por ejemplo, la secuencia de la cárcel, el mismo director de fotografía propuso un plano secuencia viendo el espacio, la arquitectura que había.

La veracidad de las imágenes de la película responden a una inquietud por situar el relato fílmico en un contexto social e históricamente determinado: es la realidad de una familia del Puerto de Valparaíso que sufre las prerrogativas de una sociedad que aniquila, puesto que en la película los niños se van alejando cada vez más y al final no queda nadie, en la última toma los niños no aparecen en escena: cuando están hablando los compadres en la cárcel, los niños han sido tragados por la ciudad. La película termina en un hoyo; empieza en los cerros arriba y termina en los subterráneos de "El Yako"8. La ciudad se los traga también desde un punto de vista formal, con las voces en off de Mario y María, quienes se autoengañan diciendo, por ejemplo, que la niña trabaja como costurera9.

Para Aldo Francia, una película debe interesar al espectador. Cuando alguien hace cine, generalmente, busca su clientela, ¿Para quién la hago? ¿Clase alta, media, baja? Por ejemplo, si alguien no entiende y se ríe, no importa, porque está la parte subliminal, la capacidad de entendimiento la tienen todos; cuando a la gente le preguntaban cuál era el tema de la película, empezaban a hablar y de pronto se daban cuenta que en la película no habían malos y que el malo era el sistema ${ }^{10}$.

\section{Mumbai; ciudad y mosaico social en los ' 80}

En Saalam Bombay (1988) -la otra ciudad puerto, en este caso de la Indiase exploran las características e impacto social y cultural de la infancia abandonada como cruda realidad social. El mosaico de la infancia abandonada retratado por Mira Nair, su directora, se resignifica cultualmente al cine de Sajyajit Ray, maestro del cine de la India, que con la trilogía sobre las Vidas de $A p u^{11}$, elevo el cine producido en este país a categoría internacional.

\footnotetext{
${ }^{8}$ Bar del sector barrio-puerto; enclave de prostitución y ambientes clandestinos de la época en Valparaíso.

${ }^{9}$ Extracto de la entrevista realizada por el suscrito al director de cine Aldo Francia. Valparaíso, 1988.

${ }^{10}$ Idem.

${ }^{11}$ Pather Pamchali (1955), Aparajito (1956) y Apur Sansar (1959), forman parte de la Trilogía de Apu.
} 
Krishna, el niño-hombre que afronta la dureza del castigo familiar por la pérdida de la motocicleta de su hermano mayor y, cuyo sino trágico desarrolla por las callejas y oscuras zonas de la ciudad de Mümbai. La puesta en cuadro de M. Nair recorre la ciudad mediante planos largos, a distancia y cámara en mano; apelando con ello a un tiempo real, próximo a una estética del cine neorrealista italiano de los años ' 40 y '50 y en consonancia con la estética lograda en Valparaíso, mi amor.

La temática de la película se desarrolla en locaciones reales de la ciudad de Mümbai; las calles, patios y casas desvencijadas -auténticos sedimentos sociales- escenifican y frasean las diversas categorías de prostitución y explotación laboral infantil. La ciudad también incumple con los sueños y fantasías de los niños, quienes se transforman en moneda de cambio o, incluso, de ajusticiamiento. Por ejemplo, el mortecino plano del asesinato perpetrado por Krishna, Mira Nair, lo representa sin analogías; lo objetiva en cuanto a su carga social y universaliza a otras realidades, hacia otros contextos de mercadeo urbano de la infancia; abonada ahora a nuestra licuada modernidad digital.

Mümbai en la actualidad es la ciudad de la India con mayor PIB ${ }^{12}$, cuenta con índices de sobreconsumo, exportaciones e importaciones a escala planetaria. O sea, la modernidad sólida y líquida descritas por Bauman se modelan pese a los bolsones de pobreza y miseria infantil declarados en las imágenes de Saalam Bombay -especie de microestructuras sociales sin trama color- que operan en las antípodas de los medios masivos, de las imágenes combustibles y degradadas por las pantallas de mercado del Gran Hermano (Canclini, 2012). Por esto, en el marco de las sibilinas premisas macroeconómicas y transnacionales, la problemática de la infancia abandonada, o la infancia en situación de pobreza, se invisibilizan socialmente como constructo antropológico y cultural, y sólo adquieren pantalla al momento de calibrar Hacienda las variables estadísticas del daño colateral al modelo, nuestro modelo de mercado.

\footnotetext{
${ }^{12}$ La India forma parte de los países denominados del BRIC (Brasil, Rusia, India y China), los cuales determinan un cuarto de la economía mundial a la fecha. Para 2023 la India será la segunda economía mundial detrás de China, desplazando al tercer lugar a Estados Unidos, según datos y variables estadísticas del Banco Mundial. En www.bancomundial.org.
} 


\section{Persépolis; la ciudad arqueológica, la ciudad sitiada}

En la película animada Persépolis (2007), se explora respecto de la cartografía cultural del sujeto y las libertades ciudadanas en anacrónica disyunción al Estado Teocrático. Marjane Satrapi ${ }^{13}$, heredera de la historia política iraní, explora sus vivencias, sus memorias de infancia, con la fuerte carga de amor/odio de la ciudad que le reconoció su pasado y renegó su felicidad.

La ciudad capital de Irán -Tehéran- aparece escenificada a los ojos de Marjane como problemática abierta a conflictos culturales, políticos, religiosos y territoriales. Por ello, Marjane se pregunta en Persépolis por las microestructuras sociales y culturales que persisten/resisten a esta cartografía axial; suerte de ciudad-estado encapsulada al fundamentalismo religioso. De esta forma, la problemática documentada y ficcionada de los niños del Valparaíso de los '60 y los niños de Bombay en los '80, se visionan cual retrato de la infancia abandonada social y culturalmente. Ahora, si a esta realidad incorporamos la trama religioso-espiritual, a los problemas ya declarados, ya descritos; la disyunción se representa metafísica (antropológicamente incolora, virtual) a las inmediaciones de nuestra humanidad a escala humana ${ }^{14}$.

\footnotetext{
${ }^{13}$ Marjane Saatrapi, es hija única de una familia de Teherán descendiente de la dinastía Kayar que reinó en Persia de 1781 a 1925, hasta que su último representante, Ahmad Shah, bisabuelo de Satrapi, fue depuesto en 1925 por Reza Pahlavi. Satrapi se introdujo en el mundo del cómic de la mano del dibujante y guionista David B, quien le sugirió narrar de este modo sus recuerdos de infancia en Irán. Nace así la novela gráfica Persépolis, una obra autobiográfica que arranca en los momentos finales del régimen del Sha y que da cuenta de las dificultades de vivir bajo un estado teocrático y de las distintas formas de seguir viviendo una vida laica pese a la vigilancia de los guardianes de la revolución y de los vecinos oportunamente convertidos a un islamismo más militante que el del propio gobierno. La obra, publicada en cuatro volúmenes, alcanzó un gran éxito de crítica y público y fue adaptada por ella misma y Vincent Paronnaud al cine de animación (junio de 2007), animando a su autora a seguir por el camino de la historieta. Actualmente Marjane Saatrapi realiza en un montaje plástico, escénico y gráfico con el símbolo del cine francés, Catherine Deneuve, Rive Gauche, que corresponden a diversos hitos urbanos de la ciudad de París, en el marco de los 160 años de los clásicos almacenes Le Bon Marche. En es-es.facebook.com/MarjaneSatrapiAuthorn.

${ }^{14} \mathrm{Al}$ momento de realizar la lectura de esta Comunicación las noticias internacionales grafican nuevas estrategias del grupo Talibán en Afganistán al emplear niños-bomba al servicio de la misión político-religiosa www.infanciahoy.com/despachos.asp?cod_des=9366\&ID...192. También en www.publico.es/.../los-talibanes-matan-a-una-nina-bomba-en-afganis...n
} 
Finalmente esta curatoría cinematográfica ficciona, sitúa y devela los pliegues y repliegues de la memoria y territorio de ciudades patrimonio cultural y arqueológico de la humanidad -léase Valparaíso, Mümbai, Persépoliscuyas territorialidades se orillan a través de mojones de pobreza y marginalidad infantil, las cuales se representan licuadas a fundamentalismos de mercado y religiosos en plena era digital.

\section{Bibliografía.}

BAUMAN, Z. (2003): La ciudad sitiada. Fondo Cultura Económica, México D.F.

BAUMAN, Z. (2009): Ética posmoderna. Siglo veintiuno, México D.F.

GARCÍA CANCLINI, N. (2010): Culturas hibridas; formas de entrar y salir de la modernidad. Paidós, Barcelona.

GARCÍA CANCLINI, N. (2012): La sociedad sin relato. Antropología y estética de la inminencia. Katz, B. Aires/Madrid.

SANJINÉS, J. (1979): Grupo Ukamau, teoría y práctica de un cine junto al pueblo. Siglo veintiuno, México D. F.

\section{Otras fuentes de referencia.}

JORGE SANJINÉS en el Portal de cine boliviano www.frombolivia.com/directores/jorgesanjines.html

PORTAL de cine boliviano www.frombolivia.com

WwW.guiadelcomic.com > www.guiadelcomic.com/comics/index.htm

ENTREVISTA realizada a Aldo Francia en la ciudad de Valparaíso, en el marco de la investigación realizada por el suscrito para la tesis del pregrado en Historia del Arte de la Universidad de Chile, 1988.

ENTREVISTA realizada al cineasta chileno R. Ruiz, en el marco de la investigación realizada por el suscrito para la tesis del pregrado en Historia del Arte de la Universidad de Chile, 1988. 